\title{
CEREBROSPINAL FLUID CYANIDE AFTER NITROPRUSSIDE INFUSION IN MAN
}

\author{
Pierre A. Casthely, James E. Cottrell, Katie P. Patel, Arthur Marlin and \\ HERMAN TURNDORF
}

\begin{abstract}
Sodium nitroprusside (SNP) is frequently used as an hypotensive agent for clipping of intracranial aneurysms, repair of arteriovenous malformations and resection of vascular tumours. Cyanide $(\mathrm{CN})$, which is its main metabolic product, has been recovered from the cerebrospinal fluid (CSF) of the rat after intravenous administration of $\mathrm{CN}$, but recovery of $\mathrm{CN}$ from CSF after SNP has not been reported in man.

Seven consenting adults were studied. Adequate premedication was provided with pentobarbitone $2 \mathrm{mg} \cdot \mathrm{kg}^{-1}$ and atropine $0.4 \mathrm{mg}$ one hour before operation. Anaesthesia was induced with thiopentone $8 \mathrm{mg} \cdot \mathrm{kg}^{-1}$ and maintained with nitrous oxide 60 per cent with oxygen and supplemental fentanyl $0.05 \mathrm{mg}$ and pancuronium $0.5-1 \mathrm{mg}$ as needed. Lumbar subarachnoid, radial artery, central venous, and Foley urinary catheters were inserted. Arterial carbon dioxide tension $\left(\mathrm{Pa}_{\mathrm{CO}_{2}}\right)$ was maintained between $4.6-5.32 \mathrm{kPa}$ (35-40 torr) with an Air Shields ventilator. Red cell, plasma and CSF cyanide were measured using a digital ionanalyzer before and at 30 minutes interval after infusing SNP at a rate sufficient to maintain the blood pressure at two thirds of the pre-operative level. Average total dose of SNP was $0.51 \mathrm{mg} \cdot \mathrm{kg}^{-1}$. CN concentration in the red blood cells increased from $9.5 \pm 2.05$ to 75.12 \pm 17.12 . Plasma $C N$ increased from $0.54 \pm 0.05$ to $1.09 \pm 0.14 \mu \mathrm{g}$ per cent. CSF $\mathrm{CN}$ increased from $0.11 \pm 0.04$ to $0.72 \pm 0.07 \mu \mathrm{g}$ per cent.

Significant increase in red cell, plasma and CSF CN occurred five minutes after the start of SNP and returned to the preoperative level 19 hours later.

Conclusion

CN crosses the blood-brain barrier. Large doses of SNP in patients with neurovascular brain disorders warrants caution because cytotoxic cerebral oedema and $\mathrm{CN}$ encephalopathy have been described in rats after intravenous injection of sodium cyanide or exposure to hydrogen cyanide.
\end{abstract}

Key Words: Cerebrospinal Fluid, nitroprusside, cyanide.

SODIUM NITROPRUSSIDE (SNP) is frequently used to induce hypotension for clipping of intracranial aneurysms, repair of arteriovenous malformations and resection of vascular tumours. 1 Toxic blood levels of cyanide (CN) can result from metabolic degradation if SNP is administered acutely at a rate greater than 10 $\mu \mathrm{g} \cdot \mathrm{kg}^{-1} \cdot \mathrm{min}^{-1}, 2^{2} \mathrm{CN}$ has been recovered in

Pierre A. Casthely, M.D., Assistant Professor; James E. Cottrell, M.D., Professor and Chairman: Department of Anesthesiology, State University of New York, Downstate Medical Center, Brooklyn, New York 11203. Katie P. Patel, M.D., Assistant Professor, Clinical; Herman Turndorf, M.D., Professor and Chairman; Department of Anesthesiology. Arthur Marlin, M.D., Resident, Department of Neurosurgery; New York University Medical Center, New York, N.Y. 1006, U.S.A

Correspondence and Reprint Requests to: Pierre A. Casthely, M.D., Department of Anesthesiology, State University of New York, Downstate Medical Center, 450 Clarkson Avenue, Box 6, Brooklyn, New York 11203 , U.S.A.

Canad. Anaesth. Soc. J., vol. 28, no. 3, May 1981 cerebrospinal fluid (CSF) of the rat after intravenous $\mathrm{CN}$ administration and may damage the brain cells sufficiently to cause encephalopathy as a result of histotoxic anoxia. ${ }^{3.4}$

We have previously shown progressive increase in red cell and plasma cyanide concentration when SNP was administered continuously, but recovery of $\mathrm{CN}$ from CSF after SNP infusion in man has not been reported.

\section{METhOD}

Seven consenting adults, classified for surgery as ASA II, were scheduled for induced hypotension for clipping of aneurysms or ligation of arteriovenous malformation. All were premedicated with pentobarbitone $2 \mathrm{mg} \cdot \mathrm{kg}^{-1}$ and atropine $0.4 \mathrm{mg}$ one hour before induction of anaesthesia. Anaesthesia was induced with thiopentone 8 $\mathrm{mg} \cdot \mathrm{kg}^{-1}$ and maintained with nitrous oxide 60 per cent with oxygen and $0.05 \mathrm{mg}$ supplements of fentanyl as needed. Pancuronium $0.1 \mathrm{mg} \cdot \mathrm{kg}^{-1}$ 
was given intravenously to facilitate tracheal intubation and to provide muscle relaxation. Radial artery, central venous and Foley urinary catheters were inserted. A soft Portex ${ }^{(1)}$ catheter was introduced into the subarachnoid space through a \#17 Tuohy needle for CSF drainage and CSF CN determination. Arterial carbon dioxide $\left(\mathrm{Pa}_{\mathrm{CO}_{2}}\right)$ was maintained between 4.5-5.3 $\mathrm{kPa}$ (34-40 torr) with an Air Shields Ventilator. SNP (0.01\% solution) was given by continuous intravenous infusion at a rate sufficient to reduce arterial pressure to two-thirds of the preoperative systolic level. Blood and CSF samples obtained simultaneously before, 15 minutes and subsequently at 30 minute intervals up to 240 minutes after starting SNP were analyzed for $\mathrm{CN}$ using a specific ion electrode calibrated by plotting a digital ionanalyzer standard $\mathrm{CN}$ solutions $\left(10^{-2}\right.$, $10^{-4}, 10^{-16}, 10^{-32}$ ) against the $\log$ of the $\mathrm{CN}$ concentration. Blood and CSF CN concentration were then determined by referring the millivolt electrode potential of the Digital lonanalyzer to the standardized response curve. CSF CN was not calculated after 18 hours.

\section{RESULTS}

Total dosage of SNP administered to each patient was $0.51 \mathrm{mg} \cdot \mathrm{kg}^{-1}$. Infusion time was 160 \pm 15 minutes. Red blood cell $\mathrm{CN}$ concentration increased from $9.5 \pm 2.05$ to $75.12 \pm 17.12 \mu \mathrm{g} \mathrm{per}$ cent (Figure 1). Plasma CN increased from $0.54 \pm$ 0.05 to $1.09 \pm 0.14 \mu \mathrm{g}$ per cent. CSF CN increased from $0.11 \pm 0.04$ to $0.72 \pm 0.07 \mu \mathrm{g}$ per ent (Figure 2).

These significant increases of $\mathrm{CN}$ in red cells, plasma and CSF occurred at 45 minutes and peaked at $210 \pm 30$ minutes after the start of SNP. Red cell, plasma and CSF CN returned to normal 19 hours afterwards (Table I).

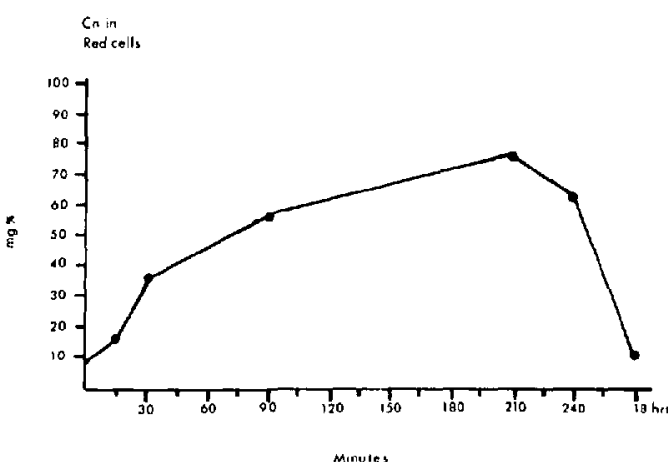

Figure 1 Red cell CN before and after SNP infusion in man.

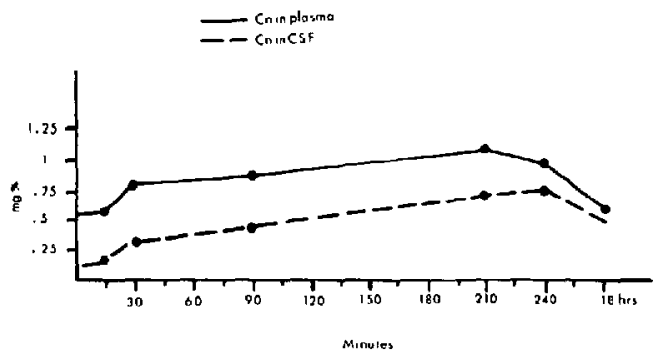

FIGURE 2 Plasma and CSF CN before and after SNP infusion in man.

\section{Discussion}

$\mathrm{CN}$ is a small molecule (molecular weight 26) which can diffuse across membranes and transfer from plasma to CSF across the blood-brain barrier. The possible crossing sites include the choroid plexus, the arachnoid membrane overlying the subarachnoid space, and brain extracellular space. CN may also enter the CSF by an excretory "sink" action of CSF which extracts $\mathrm{CN}$ from the brain. ${ }^{5}$

Anoxic brain damage in experimental animals exposed to $\mathrm{CN}$ results from inhibition of cytochrome oxidase. ${ }^{3}$ Differential sensitivity to brain injury may be due to local variations in metabolic demand. White matter (callosum and striatum) has a lower cytochrome oxidase concentration than gray and is therefore more sensitive to $\mathrm{CN}$, although gray matter injury can also occur following exposure to high concentration of $\mathrm{CN}$ or exposure to low concentration for long periods. Ischaemic areas of brain are more sensitive to $\mathrm{CN}$ induced anoxia. ${ }^{6}$

Autoregulation and collateral circulation normally allow for compensatory increase of flow in response to moderate hypoxia or ischaemia. Unilateral carotid artery ligation, for example, does not result in brain injury if autoregulation and collateral circulation are intact, but if a normally innocuous dose of cyanide is administered during the period of ligation, brain damage will occur. ${ }^{3}$

Calculating the maximum amount of $\mathrm{CN}$ which can be originated for each milligram of SNP, we found that only 17 per cent was recovered from plasma red cells, leaving 83 per cent for metabolic interference by binding the cytochrome oxidase system. Direct contact of $\mathrm{CN}$ with brain tissue in animals results in depression of oxidative metabolism.

In patients with disrupted cerebral autoregulation SNP should be administered carefully and 


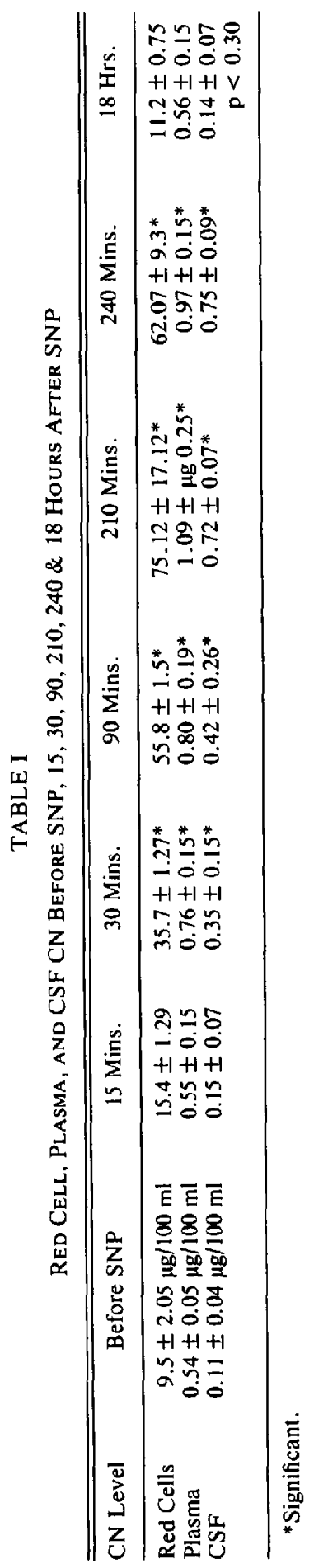


attention paid to the fact that $\mathrm{CN}$ crosses the blood-brain barrier and can be recovered in CSF. We do not know the effect of CSF CN on recovery of our patients. However, two of our patients who received more than $1 \mathrm{mg} \cdot \mathrm{kg}^{-1} \mathrm{SNP}$ recovered slowly despite adequate reversal with naloxone.

How much of this postanaesthetic brain depression is due to CSF CN is not known. We postulate, however, that high concentrations of $\mathrm{CN}$ in CSF can produce a histotoxic hypoxia in patients with an abnormal blood-brain barrier and especially in those with increased intracranial pressure and decreased cerebral perfusion pressure who may develop tachyphylaxis to SNP.

\section{ConcLusion}

$\mathrm{CN}$ resulting from degradation of SNP crosses the blood-brain barrier in patients with intracranial neurovascular disorders. Despite control of blood pressure, $\mathrm{CN}$ recovery from CSF warrants cautious administration.

Cytotoxic cerebral oedema and $\mathrm{CN}$ encephalopathy have been reported in animal studies after intravenous injection of sodium thiocyanate and concommitant ischaemia has been shown to precipitate the development of early encephalopathy in rats. The dose of SNP administered to a patient with impaired autoregulation or with decreased intracerebral collateral circulation should probably be less than $0.7 \mathrm{mg} \cdot \mathrm{kg}^{-1}$ acutely administered.

\section{REFERENCES}

1. Stoyka, W.W. \& Schultz, H. The cerebral response to sodium nitroprusside and trimethaphan controlled hypotension. Canad. Anaesth. Soc. J. 22: 275-283, (1975).

2. KATZ, R.L. Dose limits to acute nitroprusside therapy challenged. Anesthesiology 47: 395-396, (1977).

3. Levine, S. \& Stypulkowski, W. Experimental cyanide encephalopathy. AMA Arch. Path. 67: 306-323, (1959).

4. Levine, S. \& Wenk, E.J. Cyanide encephalopathy produced by intravenous route. J. Nervous Mental Dis. 129: 302-305, (1959).

5. RAPPAPORT, S. Blood-Brain Barrier in Physiology and Medicine, 1st ed. Raven Press: New York (1976).

6. Brierley, J., et al. Cyanide intoxication in the rat: Physiological and neuropathological aspects. J. Neurol. Neurosurg. Psych. 39: 129-140 (1976).

7. Levine, S. \& Strpulkowski, W. Effect of ischemia on cyanide encephalopathy. Neurology 9: 407-411, (1959).

\section{RÉSUMÉ}

Le nitroprusside de sodium est l'agent hypotenseur par excellence utilisé au cours des interventions intracranienne telles que malformation artério-veineuse, excision de tumeur vasculaire, réparation d'anévrysmes cérébraux. Le cyanure, principal métabolite du SNP a été retrouvé dans le liquide céphalo-rachidien du rat après administration intraveineuse de thiocyanate de sodium. Aussi une étude a été entreprise sur sept volontaires en vue de déterminer la quantité de cyanure présente dans le LCR de l'homme à la suite d'une injection intraveineuse de la substance susmentionnée (SNP).

Ces patients ont reçu pentobarbitone $2 \mathrm{mg} \cdot \mathrm{kg}^{-1}$ et atropine $0.4 \mathrm{mg}$, une heure avant l'intervention chirurgicale. L'induction anesthésique a été réalisée au thiopentone $8 \mathrm{mg} \cdot \mathrm{kg}^{-1}$ et au protoxyde d'azote 60 pour cent. Du fentanyl et du pancuronium ont été ajoutés au besoin. Des cathéters ont été placés, respectivement dans le canal rachidien, l'oreillette droite et l'artère radiale. $\mathrm{La} \mathrm{PCO}_{2}$ a été maintenue entre 4.66 et $5.32 \mathrm{kPa}$ (35 et 40 torr) pendant toute la durée de l'intervention. La quantité de cyanure contenue dans le plasma, les globules rouges et le LCR a été calculée à l'aide d'un ionisateur digital à des intervalles de 30 minutes après l'injection de SNP. La pression artérielle de ces patients a été réduite aux $2 / 3$ de la valeur trouvée avant l'opération. Pour une dose moyenne de $0.51 \mathrm{mg} \cdot \mathrm{kg}^{-1}$ de SNP injecté, la concentration de cyanure retrouvée dans les globules rouges passait de $9.5 \pm 2.05$ à $75.12 \pm$ 17.12. Au niveau du plasma cette concentration s'était élevée de $0.54 \pm 0.05$ à $1.09 \pm$ $0.14 \mu \mathrm{g}$ pour cent. Dans le LCR, le cyanure atteignait une concentration de $0.11 \pm 0.4$ à 0.72 $\pm 0.07 \mu \mathrm{g}$ pour cent.

Une augmentation considérable du cyanure dans les globules rouges, le plasma et le LCR a donc été observée 45 minutes après l'administration de SNP par voie intraveineuse chez l'homme, augmentation qui n'était plus notée 19 heures après l'injection.

\section{Conclusion}

Le cyanure traverse la barrière sanguine cérébrale et son administration à dose élevée sous forme de SNP exige une attention spéciale chez les patients présentant des troubles dans le fonctionnement de cette barrière. Il est à noter que des complications sérieuses telles que l'oedème cérébral et l'encéphalopathie ont été enregistrés chez le rat. 